\title{
The use of high-resolution LiDAR scanning in the research of small landslides based on Croatian examples
}

doi: $10.4154 / g c .2022 .13$

Dear readers,

This issue, $75 / 1$ is mostly dedicated to the environmental impact of landslides, which, due to current climate change, are becoming more and more pronounced around the world and in the Republic of Croatia. The six papers (BOSTJANČIĆ et al., 2022, Fig. 1 polygon 1; FILIPOVIĆ et al., 2022, Fig. 1 polygon 2; FRANGEN et al., 2022, Fig. 1 polygon 3; GULAM et al., 2022, Fig. 1 polygon 4; PODOLSZKI et al., 2022, Fig. 1 polygon 5; POLLAK et al., 2022, Fig. 1 polygon 6) focusing on landslides are the result of the work of a large team of people from the Croatian Geological Survey, carried out within the framework of the safEarth project, cofinanced by the ERDF and IPA II funds of the European Union.

As a part of the Interreg IPA - Cross-border Cooperation Programme Croatia - Bosnia and Herzegovina - Montenegro 2014-2020, the safEarth project was based on cross-border cooperation of four partner institutions, namely the Croatian Geological Survey (lead partner), Geological Survey of Montenegro, Faculty of Mining, Geology and Civil Engineering of the University of Tuzla and the Development Agency Žepče d.o.o. The main project activities were focused on landslide susceptibility maps (LSM) as one of the most important data sets in spatial planning that have not been recognized as such in any of the project partner countries.

LSMs show the subdivision of the terrain into zones that have a similar spatial probability of landslide occurrence (COROMINAS et al., 2014). Their derivation is usually based on the principle that the past is a guide to the future, i.e., areas similar to those that have experienced landsliding in the past are likely to experience landsliding in the future (VARNES, 1984). For determination of past landslide activity within a certain area, it is crucial to establish and further analyse the landslide inventory (FELL et al., 2008).

The articles presented in this issue represent pioneering attempts at establishing and analysing landslide inventories within six pilot polygons distributed in three Croatian counties, namely Zagreb, Sisak-Moslavina, and Brod-Posavina (Fig. 1). The polygon positioning principle was determined to cover as many geological units within these counties as possible. The aim was to quantify their landslide susceptibility, which was the general goal for all six of the presented papers.

It is crucial to emphasize that all presented landslide inventories are LiDAR-based and derived from a $0.5 \mathrm{~m}$ resolution di-

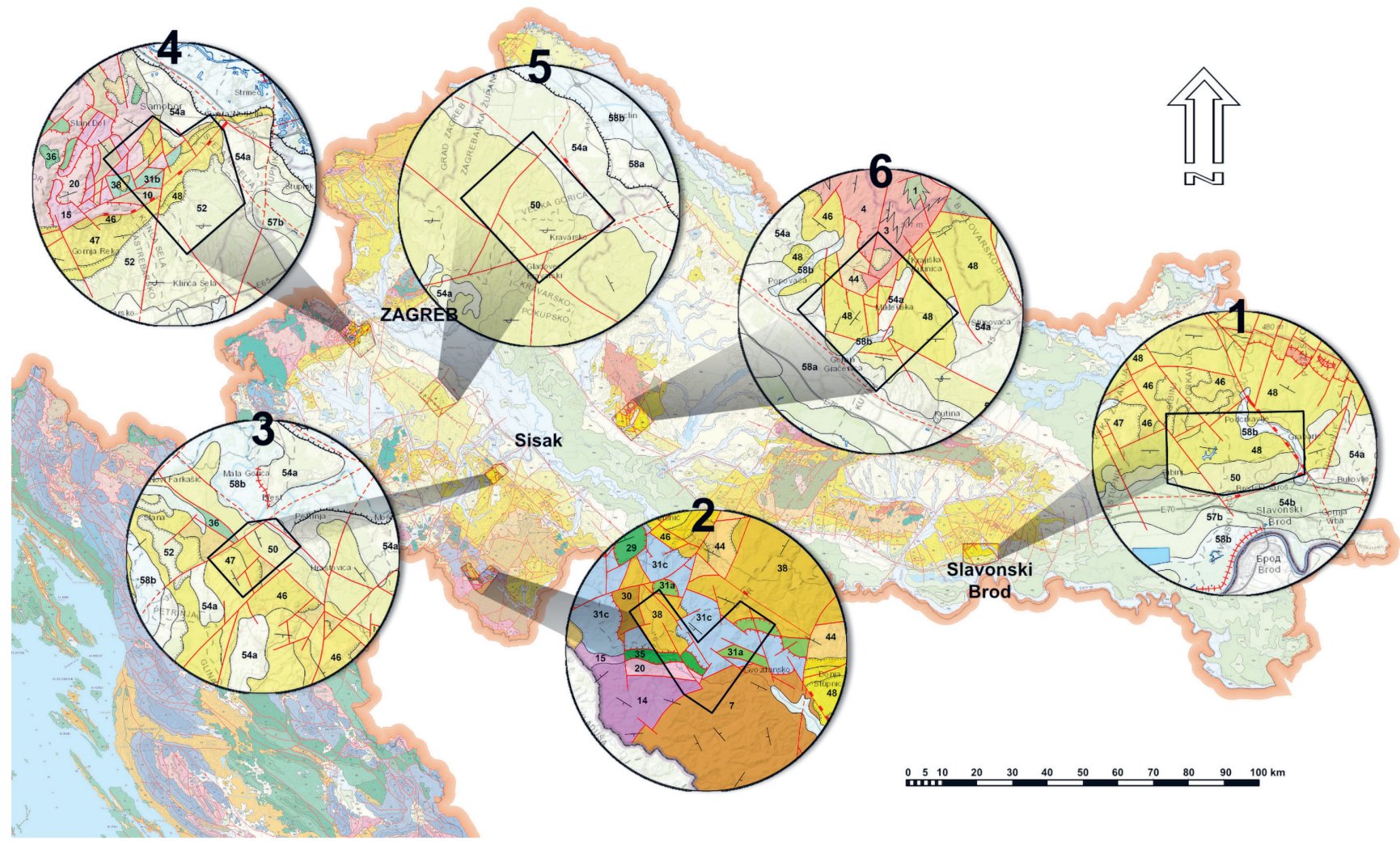

Fig. 1 - Spatial distribution of the study polygons on the geological map of the Republic of Croatia M 1: 300.000 (HGI, 2009) 
gital terrain model. Additionally, high-resolution orthophoto maps with approximately $10 \mathrm{~cm}$ ground sampling distances were also used. The characteristics of the remote data used are described in more detail in each of the six presented papers. Still, it is important here to point out that these data cover an area of approximately $310 \mathrm{~km}^{2}$, and that landslide inventories are prepared for the entire scanned area.

\section{REFERENCES}

BOSTJANČIĆ, I., AVANIĆ, R., FRANGEN, T. \& PAVIĆ, M. (2022): Spatial distribution and geometric characteristics of landslides with special reference to geological units in the area of Slavonski Brod, Croatia. doi: 10.4154/gc.2022.03

COROMINAS, J., VAN WESTEN, C., FRATTINI, P., CASCINI, L., MALET, J.-P., FOTOPOULOU, S., CATANI, F., VAN DEN EECKHAUT, M., MAVROULI, O., AGLIARDI, F., PITILAKIS, K., WINTER, M.G., PASTOR, M., FERLISI, S., TOFANI, V., HERVA'S, J. \& SMITH, J.T. (2014): Recommendations for the quantitative analysis of landslide risk.- Bulletin of Engineering Geology and the Environment, 73, 209-263. Doi: 10.1007/s10064-013-0538-8
FELL, R., COROMINAS, J., BONNARD, C., CASCINI, L., LEROI, E. \& SAVAGE, W.Z. (2008): Guidelines for landslide susceptibility, hazard and risk zoning for land use planning.- Engineering geology, 102/3-4, 85-98. doi: 10.1016/j. enggeo.2008.03.022

FILIPOVIĆ, M., MIŠUR, I., GULAM, V. \& HORVAT, M. (2022): A case study in the research polygon in Glina and Dvor municipality, Croatia-landslide susceptibility assessment of geological units. doi: 10.4154/gc.2022.04

FRANGEN, T., PAVIĆ, M., GULAM, V. \& KUREČIĆ, T. (2022): Use of LiDAR-derived landslide inventory map in assessing Influencing factors for landslide susceptibility of geological units in the Petrinja area (Croatia). doi: 10.4154/gc.2022.10

GULAM, V., BOSTJANČIĆ, I., HEĆEJ, N., FILIPOVIĆ, M. \& FILJAK, R. (2022): Preliminary analysis of LiDAR-based landslide inventory in the area of Samobor, Croatia. doi: $10.4154 / \mathrm{gc} .2022 .11$

PODOLSZKI, L., KUREČIĆ, T., BATESON, L. \& SVENNEVIG, K. (2022): Remote landslide mapping, field validation and model development - An example from Kravarsko, Croatia. doi: 10.4154/gc.2022.01

POLLAK, D., HEĆEJ, N. \& GRIZELJ, A. (2022): Landslide inventory and characteristics, based on LiDAR scanning and optimised field investigations in the Kutina area, Croatia. doi: $10.4154 / \mathrm{gc} .2022 .02$

VARNES, D.J. \& IAEG (1984): Landslide Hazard Zonation: A Review of Principles and Practice. UNESCO, Paris, 63 p.

Kenan Mandžić, Guest Editor

Vlatko Gulam, Guest Editor Lidija Galović, Editor-in-Chief 